\title{
Law and economics of training: a taxonomy of the main legal and institutional tools addressing suboptimal investments in human capital development.
}

\author{
1. Introduction \\ In the knowledge economy firm training is widely recognized as a key ingredient to \\ maintain and enhance the organizations' competitiveness through the upgrading of \\ workers' competences and skills. The increasing specificity of qualifications, the \\ relevance of intangible networks, together with the persistent need to place each job in \\ a well-defined area, make the firm's demand of human capital more complex than in the \\ past. The characteristics of both ongoing and future technological and organizational \\ innovation processes imply that specific skills need to be constantly adapted to changing \\ circumstances. On the other hand creativeness, abstract reasoning, problem solving, and \\ decision making are increasingly relevant for triggering new skills and competences. The \\ challenges posed by globalization can only be met if workers attain high levels of \\ competences in this continuous and diversified up-skilling process.
}

Within this framework firm training is expected to increase labour productivity by contributing to create new skills and to advance the existing ones. Indeed, although the return of training on firm performance is still characterized by the uncertainty of the employer about its actual size, an increasing body of evidence indicates the existence of a positive relationship among training, labour productivity and wages (Bishop 1994; Grilliches and Mairesse 1995; Groot 1999; Zwick 2002; Conti 2005; Dearden et al. 2006; Almeida and Carneiro 2009; Sepulveda 2010; Konings and Vanormelingen 2010).

This essential role of training raises relevant issues in terms of the size of the corresponding investment. Not only does it differ from firm to firm and from worker to worker, but it is also likely to be suboptimal. Firms that bear training costs may not be able to fully appropriate the benefits arising from the associated growth of human capital. Moreover training is a merit good, since its value may be greater for society than for the parties directly involved in the process. Efficiency reasons thus justify the existence of legal and/or institutional tools, either voluntary or mandatory, aimed at addressing suboptimal investments in human capital development.

The purpose of this study is to point out the main inefficiencies underlying training investments and draw a taxonomy of the main legal and institutional devices able to stimulate their amount. Training is on the top of the political agenda in many countries. The European Union is committed to increase adults' participation in lifelong learning and to improve the quality of training programs and institutions (Lisbon Strategy, Education and Training 2010 Work Programme). However, while training is of increasing political interest, a proper tool-box for policy makers is still missing. 
The rest of the paper is structured as follows. Section 2 refers to the relevant theoretical framework. Section 3 analyses the main inefficiencies underlying training. Section 4 discusses the possible legal and institutional solutions to address these inefficiencies. Section 5 concludes.

\section{Theoretical framework.}

The current thinking on training is shaped by the human capital theory, as formalized by the seminal work of Mincer (1958) and Becker (1964). By adopting a neoclassical approach, and assuming that labour and products markets are perfectly competitive, human capital theory views training as an investment that has a positive impact on productivity and wages, though at a cost. However, the effects on productivity are not necessarily shifted to wages. It depends on the type of training received by the worker. In this respect the standard theory draws a crucial distinction between general and specific training.

General training leads to one-to-one increase in the wage of the worker as the training activity increases his productivity, no matter what firm he works for. A firm is deterred from optimally investing in training because trained workers will reasonably move to another firm as soon as they become upskilled. The training firm is then unable to capture the attached benefits. An optimal investment could only originate from the decisions of rational workers who are willing to pay the full cost of general training by accepting lower wages during the training period, given that productivity gains will entirely flow to future wages.

Conversely, specific training is characterized by the provision of professional skills that can hardly be transferred from one firm to another. This has economic consequences on firm's behaviour. Since specific training only benefits the firm, rivals will not make pay offers to trained workers as their status in the labour market does not increase in value. Accordingly, it is rational for firms to incur these training-related costs as they receive nearly all the benefits derived from the improved labour productivity.

The main implication of traditional human capital theory is thus the incentive for the worker to invest in general training through the educational system as long as his potential return exceeds the related costs. On the other side firms are expected to entirely bear specific training investments, as the relevant benefits are entirely attached to the training organizations.

The subsequent theoretical evolution however questioned the Beckerian view, suggesting the complementarity between education and training, and between general and specific training, especially in presence of imperfectly competitive labour markets. The seminal contribution in this respect is by Rosen (1976) who argued that education improves work-related skills thus reducing training costs. Accordingly, firm training is also general in nature. Later, in the 1990s, a substantial strand of theoretical literature developed models for explaining why firms are willing to invest in general and transferable training. These models can be traced back to two different approaches.

The first approach focuses on imperfections in the skilled workers' labour market (Katz and Ziderman 1990; Autor 2001; Acemoglu and Pischke 2003) such as search costs, information asymmetries, labour market institutions, capital market imperfections. Such 
imperfections may act both on the supply-side, through institutions such as trade unions, and on the demand-side, as employers can actually enjoy market power in setting wages, thus acting in an oligopsonistic way (Brunello and De Paola 2004). Moreover, information asymmetries between employer and outside firms concerning the amount of training the worker has acquired and/or about the workers' abilities may arise (Katz and Ziderman 1990; Chang and Wang 1996; Acemoglu and Pischke 1998). These imperfections compress the wage structure in such a way that the wages of trained workers increase less steeply than productivity. As a result firms can earn part of the returns of the investments in their employees' general human capital.

The second approach acknowledges that some kind of complementarity between general and specific training may exist due to either complementary relationships among productive inputs (Acemoglu and Pischke 1999), or technical complementarities in the training process (Franz and Soskice 1995). Accordingly, complementary investments in general training generate a larger increase in productivity and a better economic performance (Barrett et al 2001; Dearden et. al. 2006) than separate investments in specific training. Moreover, technological advances and changing market mechanisms require general training in order to maintain and retrieve the employees' competences. This implies that above a certain threshold the same worker is not able to accumulate specific human capital unless he benefits of either further education or general training (Guidetti and Mazzanti 2007; Antonelli et al. 2010). In this perspective training becomes a dynamic process of specification of a complementary relationship between skills and other inputs.

Other authors even argue that the distinction between general and specific training is irrelevant for the firm's training choices (Barron et al. 1989; Veum 1995; Loewenstein and Spletzer 1999; Autor 2001) and should not imply a separate analysis of training investments, even in the absence of labour frictions. In this view a mixed training intervention always allows the firm to partially recapture its general training outlays, thanks to the presence of specific skills (Kessler and Luelfesmann; 2006). Accordingly, general and specific human capital are complementary from the firms' point of view even if their returns (and provision costs) are technologically disconnected.

\section{Main inefficiencies underlying the under-provision of training}

Let us now examine the main inefficiencies associated with firm training prior to identify the legal and institutional solutions able to address them.

First of all the assumption of complementarity between general and specific training, combined with the evidence that each training program usually contains inseparable elements of both components implies the existence of positive externalities associated with general training due to its nature of a partially non-excludable good.

Positive spillovers originate from the merit good nature of knowledge (Finegold and Soskice, 1988) and from the complementarity between training and innovation (Acemoglu 1997). The former aspect deals with the existence of benefits that go beyond those fully captured by trained workers. The latter refers to the positive interaction 
arising from the synergies between human capital development and product or process innovation. Skills are more valuable for a firm investing in new technologies, while, on the opposite side, a high rate of innovation stimulates policies for human capital development, such as training (Bresnahan et al. 2002). In both cases social marginal benefits coming from training are higher than private ones.

Some of these externalities accrue to the training firm. Training an employee increases the productivity of co-workers and total factor productivity. Likewise innovation positively affects the demand for new competencies, particularly when it involves the design of new organizational assets and the need to develop new skills. Thus firms "can achieve higher productivity only if they have a skilled workforce that is able to adopt new knowledge and technologies" (Muehlemann et al. 2011, 561). This phenomenon shifts labour demand toward more highly skilled workers relative to the less skilled (Acemoglu 2002). Moreover, a highly qualified workforce is expected to attract dynamic capital embedding new technologies.

Other externalities may spread beyond the boundaries of the firm. A trained workforce could positively affect external firms' labour productivity. Knowledge spillovers increase the probability that other firms will adopt new technologies. These effects are more likely to occur within cities and local production systems taking the form of "local human capital externalities" (Moretti 2010). In general, high skilled workers show a greater propensity to spend in health care and a lower propensity to commit crimes due to the higher wages they expect to earn during their residual working life. The complementarity between training and innovation also increases the rate of depreciation/destruction of human capital engendered by technological and organisational changes inherent in the economic system. Accordingly, training investments should also allow the overall workers to compensate such depreciation, thus calling for further incentives for this source of human capital development.

Peculiar externalities of training are the so-called poaching externalities (Stevens 1996). They are related to the likelihood that trained workers move to outside firms offering them a higher wage after the training period. Employers would thus lose training benefits and have no incentive for providing general training to their workers. Eventually this phenomenon "can lead to an underinvestment in training because firms may be hesitant to pay for the acquisition of skills for workers who leave before the training investments are paid-off' [Mohrenveiser et al. 2010, 5]. An increase of the share of general training determines a higher likelihood of transfer of employees due to the competition among firms to seize valuable skills acquired by workers further to training intervention. In addition, the magnitude of poaching externalities depends on wage compression, which is measured by the difference between wages and marginal product.

These externalities fit into a conventional market failure framework typically calling for state involvement in order to achieve an optimal investment of society in training activities, as firms are deterred from investing sufficiently in training. However, this is not to say that state training schemes are necessarily the most appropriate way to address the issue. 
With regard to information asymmetries affecting the training firm, two main cases can be distinguished. Firstly, the firm may not observe worker's ability and propensity to learn at the moment of hiring. As a consequence the firm cannot provide the quantity and quality of training needed by each worker. Secondly, the asymmetry may concern the amount and the quality of training actually received by the worker in other firms (tacit knowledge is not easily observable). Accordingly, it may also happen that the training firm is better informed about worker's ability and effort in performing the job than the market. This makes the productivity differential associated with training partially unverifiable. Moreover, the firm is subject to a moral hazard problem during training provision, as the actual contribution of the worker to the learning activity may remain unknown (Schlicht 1996).

Not surprisingly, the effects of information asymmetries on training investments are twofold. Asymmetries about previous training may mitigate the risk of poaching as the external firms place a lower expected value on potential workers than the firm that trained them (Katz and Ziderman 1990). Accordingly, the wage offered by outside employers does not correspond to the skills actually acquired by the worker. Firms thus have an incentive to invest in general training. On the other side, information asymmetries may lead to the failure in screening more capable and productive workers, thus reducing the expected impact of training investments on productivity (Maximiano and Oosterbeek 2007). In the same sense the moral hazard problem is supposed to reduce the firm's propensity to train if the success of training depends on the effort of workers (Acemoglu and Pischke 1999).

Moving to the worker's viewpoint, information asymmetries on future earnings may incentive a potential myopic behaviour. The worker might in fact prefer a higher salary in the initial phase of his working period instead of a possible higher remuneration in the post-training period. This negative effect on training will be exacerbated if information asymmetries tie with uncertainty, bounded rationality, and liquidity constraints.

Another source of inefficiency comes from the hold-up phenomenon, which is associated with specific investment characteristics of general training. The worker can threaten the firm of changing employer once he has been trained. In the renegotiation process the worker, i.e. the non-investing party, will be able to capture part of the returns. In particular, the contractual relationship concerning workers' human capital is inherently incomplete in sectors characterized by high rates of innovation and frequent technological change (Casas-Arce 2004). This incompleteness is mitigated by the assumption of complementarity between general and specific training that lowers the incentive for the worker to change employers, thus increasing the propensity of the firm to invest in general training. Specific training in fact can be viewed as a bilateral specific investment, thereby mitigating the hold-up risk for the firm. Although external wages rise one-to-one with a worker's productivity, it may still be convenient for the worker not to quit the training firm due to the higher productivity associated with that job: "if the worker's bargaining power is sufficiently high, his share of the surplus from continued employment is above what he can realise on the external market. As a consequence, the worker captures part of the rent from specific skills" (Kessler and Luefelsmann 2006, 904). In conclusion, neither the surplus generated by the growth of 
human capital can be efficiently allocated ex ante, nor can it be easily verified ex post, thus hindering the inclusion of explicit training variables in the contractual relationship between firms and workers.

Failures in the labour market may have a positive impact on firm training. Acemoglu (1997) shows that the imperfections in the labour markets induce the firm to provide a widespread training activity, including general training, as long as the workers are not paid a wage equal to their marginal productivity and their mobility is limited. In fact the wage compression attached to imperfectly competitive labour markets may increase the incentive for firms to invest in general training. A preliminary condition for this result is that post-training productivity is increasing in respect to training intensity at a higher rate than wages. A recent empirical study confirmed this model showing a significant positive correlation between the existence of frictions in the labour market and the amount of firms' investment in training (Picchio and Van Ours 2011). Effects on training investments, however, are ambiguous due to the trade-off between the (positive) effects on firm's investment and the (negative) effects on labour demand coming from the assumption of imperfect competitive markets. The empirical analysis carried out by Manning (2003) supports the hypothesis that a perfectly competitive labour market is likely to produce an (allocative) efficient level of training.

Finally, capital market imperfections may also have spillovers on the labour market. In particular they are expected to have a negative impact on training investments by causing liquidity restrictions for workers that are asked for sharing training costs (Stevens 2001). The relevant budget constraint may in fact prevent the employee to accept a lower wage at the beginning of his career thus reducing the propensity of the firm to train newly hired workers.

\section{Legal and institutional tools to address training investments.}

\subsection{The contractual solution}

Employment contracts and other bilateral agreements are a common tool to address underinvestment in firm training through the specification of: (i) a first-period wage; (ii) training level; (iii) a second-period wage; (iv) the duration of the relation; (v) a penalty if one party does not comply with one or more clauses of the contract.

Signing a long-term contract is, like in other contexts, a first possible answer to that contractual incompleteness that characterizes training investments. The parties may agree on an employment contract long enough for allowing the firm to recover its investment through workers' enhanced productivity. This contract duration may limit the turnover of trained employees and reduce the possibility for outside firms to freeride. It would encourage firms to invest in general training (Nickell 1998), also bypassing the information asymmetries arising from the imperfect observability of training quality (Edlin and Hermalin 2000). Accordingly, open-ended employment contracts are likely to address the hold-up problem and foster training investments in so far as any early unilateral termination of the contract will result in a penalty charged to the party that 
terminates the contract. Such penalties should be high enough to incentive the separation only if there is mutual consent by both parties. An ex post bilateral monopoly in the contractual relationship thus comes out, enabling the firm to extract the costs of general training of the worker, and the worker to receive part of the benefits coming from specific training, in the case of separation (Fella 2005). Long-term contracts, however, may have a higher intrinsic value for less productive workers because of the expected loss they suffer from coming back to the labour market. This creates a potential adverse selection situation if workers are heterogeneous due to the dualism between high productivity workers and low productivity ones (Hermalin 2002). The tool of contract duration is also hindered by the presence of other drawbacks such as the high costs of an ex ante definition of a separation agreement. In this respect the existence of a shared corporate culture can play a supporting role in mitigating such costs by introducing self-enforcement elements associated with the relational aspects of employment relationship.

The same function can be performed by a non-competition clause that prevents the worker to move to a competing firm for a fixed period after contract termination. This clause is expected to induce the worker to stay with the firm after having been trained (Rubin and Shedd 1981). However a non-competition clause may be a disproportionate and costly instrument (Den Hertog 2003): for an employee, the costs of such a clause would be uncertain and, assuming him to be risk-averse, he will demand full compensation in return for the inclusion of the clause. This compensation would include a price for the acceptance of the uncertainty of the nature of future jobs, for the restriction of the choice of future jobs, and for the expected decline in future wages. Thus for the employer it would be less costly to simply add a clause into the employment contract requiring the employee to pay back the cost of the training if the employee leaves the firm within a certain number of years after completing it. Indeed it seems that employers do not see noncompetition clauses as a mean of protection of training investments, rather as a mean to pursue other goals, such as protecting information.

Hold-up risk can be addressed by providing workers with incentives to participate to training programs and contribute to training investments through "up-or-out" (Kahn and Huberman 1988) and "up-or-stay" (Prendergast 1993) clauses. The first ones provide that after an initial period of training the firm is allowed to decide whether to promote a worker acknowledging him a higher wage, or, alternatively, to fire him. The second ones establish that most productive workers will be promoted at the end of the training period while the other employees will retain their initial position. Both rules address the hold-up problem. Firm has an incentive to improve worker's skills no matter the kind of training he needs. The worker has an incentive to invest in training and actively participate to the learning process. However these clauses cannot always be implemented. The "up-or-stay" rule requires both that firms can assign wages to task and that the production process allows credible assignments of workers to task. In such cases an "up-or-out" clause is more suitable. On the other side the "up-or-out" rule does not perform well if workers can choose among various levels of investments and are heterogeneous (Leuven 2005). 
Similarly, if we assume a partially flexible wage there is also the opportunity to leverage the complementarities between the two types of training through the provision of monetary incentives to both parties. The ex ante bargaining could in fact lead to the division of the training rent between the worker and the firm through the wage setting process. This scheme is typical of apprenticeship contracts: the worker accepts a low "apprentice" wage against the provision of general training by the firm; on the other side the training firm commits to ensuring the worker a wage equal to marginal product after the end of the contract. Accordingly, apprenticeship contracts provide both parties with an incentive to invest in training in the initial phase of the worker's career. The associated risk is the post-contractual opportunistic behaviour because "one party might commit to do something at some time in the future that it might not otherwise do when that time arrives" [Malcomson et al. 2003, 199]: firms may "promise" to train the worker in exchange of the acceptance of a lower initial wage, then fully employing him in jobs he already knows without any human capital development. If this happens the amount of training and the number of trained workers will be less than the efficient level even with apprenticeship contract. The scarce empirical evidence on this topic confirms this concern showing that poaching still exists in presence of apprenticeship contracts because "poached firms fail to credibly offer long-term career perspectives" (Mohrenweiser et al., 2010, 3). This issue is typically addressed through labour market regulation, that usually impose apprenticeship contracts to have a minimum length and guarantee a wage increase at the end of the contract (see also Section 4.5).

Apprenticeship contracts or similar clauses may also mitigate inefficiencies arising from asymmetric information about workers' productivity if training is more productive and therefore more valuable to high ability workers (Chang and Wang, 1996). By accepting in advance to pay a higher wage to the trained workers at the end of their apprenticeship, the training firm is expected to "discover" the workers with a marginal product equal or higher than the wage, then retaining them after the apprenticeship. Thanks to the higher propensity to learn of high ability workers, "firms are able to offer a package of training and initially lower wages in order to induce selfselection... Workers of high perceived ability choose firms offering training in expectation of wage gains in permanent employment, while low ability workers are deterred by lower wages and limited expected gains" (Autor 2001, 1411).

Moreover, firms may look for more flexible contracts in order to adapt their workers' skills to on-the-fly innovation. As long as uncertainty (associated with technological and competitive instability) increases, firms prefer an efficient incentive scheme in terms of training participation. In this respect a possible incentive scheme is the one that rewards the actual acquisition of skills by trained employees. Such a scheme is linked to the growth of human capital: workers "compete" with each other in order to participate to training activities and get benefit from them through obtaining a better job position. Limitations of this option are associated with the difficulty of using an input variable (the skills) as a proxy for the workers' performance, and with the complexity of giving a monetary evaluation to the skills themselves, especially if they are firm-specific.

However, private training schemes negatively affect workers' intrinsic motivation. Opposite to extrinsic motivation, which relies on the incentives attached to the reward 
structure, intrinsic motivation means that the worker gets pleasure and satisfaction from performing his job which thus qualifies as it is assigned a value in itself. Unless the contractual solution is supported by attractive career paths attached to training activities, intrinsically motivated workers may thus be "crowded out" by monetary incentives (Frey and Jegen 2001) because they rely on a set of rules based on trust and fairness.

$<$ Table 1 about here>

Finally, it is essential to notice that labour contracts cannot entail institutional mechanisms associated with property rights as a solution to poaching externalities, although it is theoretically possible.

In theory a property right solution would imply a penalty for the outside firm that hires an already trained worker. In such a way contracts would internalize poaching externalities through the assignment of a property right to the training firm. Firm A, hiring the trained worker at time $t=1$, rewards firm $B$ that recruited and trained the worker at time $t=0$. Nevertheless the hard distinction between the benefits coming from training and the effects coming from education and personal skills makes the feasibility of such a solution extremely difficult. Since property rights allocation can be seen as a way of governing the division of economic rents coming from specific investments, a different treatment should be applied to heterogeneous human capital sources. Actually, however, such distinction can hardly be carried out.

But above all, in contrast with other production factors, "whoever may incur the expense of investing capital in developing abilities of the workman, those abilities will be the property of the workman himself' (Marshall 1920). This universally accepted principle requires the full assignment of property rights to the trained worker who is the only one entitled to trade his ability regardless of the most efficient allocation of such rights. In most legal systems, while firms usually do not face legal constraints in exercising property rights over their tangible assets, the training firm is not entitled to retain the ownership of the human capital embodied in its employees ${ }^{1}$.

\footnotetext{
${ }^{1}$ The only application of a property rights solution is found in the labour market for professional football players before it was challenged by the European Court of Justice. In this market if a player's contract was still in force the transfer from a club to another one could only be carried out if the old club agreed to leave the player, no matter whether the player had actually complied with the legal period of notice or not. As a consequence a transfer fee was freely negotiated between the old club and a new one. After the contract had expired transfers could not be prevented by the old club, but National Football Associations set a transfer fee the club could demand. In the European Union however such a practice has been strongly limited further to a sentence of the European Court of Justice (European Court of Justice, 15th December 1995, case C-415/93, Union Royale Belge des Sociétés de Football Association ASBL and Others v Jean-Marc Bosman and Others). EU Commission appreciated this decision, arguing that before this trial football players market could be compared to a "system of slavery", thus supporting the unlawfulness of assigning property rights to skills and abilities. On the other side the main football associations (FIFA and UEFA) claimed that transfer fees were a compensation for player's education costs plus the education costs for the talents which have not become professionals in accordance with a property right solution. Currently the legal regime of football players' labour market allows transfer fees for valid contracts, but there are no transfer fees at all for expired contracts (Fees and Muhlheuber 2002).
} 


\subsection{CSR as a self-regulatory solution.}

Contractual solutions typically fail in leveraging on factors such as trust, values and corporate culture for committing both parties to invest in training. This outcome can be achieved through corporate social responsibility (CSR), an explicit self-regulatory tool that binds the firm to fulfil a fiduciary duty towards their stakeholders on a voluntary basis (European Commission 2002). These duties include the pursuance of worker's interests and objectives through social and relational rewards. With regard to this category of stakeholders, CSR is specifically seen as a set of rules aimed at "increasing the quality of life of the workforce and their families as well as the local community and society as a whole" (The World Business Council for Social Development 2000). Accordingly, training opportunities are a possible channel of a CSR strategy (Sarti e Hulkko-Nyman 2011) which may properly be regarded as a tool for promoting the firm's investment in workforce human capital.

The economic prescription, however, is different according to the theoretical approach that is adopted, either neoclassical or institutional.

In a neoclassical perspective CSR practices are seen as an answer of the firm to the existing incentive structure in the markets of goods, capital and labour. In adopting a CSR policy the firm considers direct benefits of these practices and relevant positive externalities in a long term profit maximization perspective (Friedman 1995). Since the turnover of high skilled workers is necessarily a major concern for this kind of firms, a strategic CSR may represent an effective tool in addressing it. In particular, taking intrinsic motivation as exogenous and under the further assumption that workers' motivation has a positive impact on productivity and loyalty to the firm, CSR is seen as a screening device to attract motivated workers who would rather work in socially responsible companies (Brekke and Nyborg 2005). Then training is expected to be more profitable for these firms. Higher productivity will increase the return of training investments, while higher loyalty will decrease the probability that a worker quits the firm at the end of the upskilling process.

Yet the neoclassical perspective is not sufficient to provide a satisfactory explanation of the role that CSR can take with regard to firm training. This view does not properly address the efficiency of the company as a complex organization. In this respect we can refer to the institutional approach formalized by Sacconi $(1997 ; 2005)$. Assuming that "(neither) complete contracts related to transactions in the long run (nor) all-inclusive or detailed public regulation are either not cognitively possible or too expensive tools to be implemented" (Sacconi 2005, 111) CSR becomes a valuable system of governance that rules the allocation of rights and responsibilities among all the stakeholders toward an efficient distribution of the firm's surplus, while at the same time minimizing transaction costs and mitigating problems of incomplete contracts thanks to the cooperative behaviour of all the participants to the firm.

In this view corporate culture and ethical values embedded in corporate codes are crucial, since they allow the asymmetry of information to be overcome, and give incentives to the stakeholders to behave in a cooperative way. Moreover the adherence 
to social responsibility may have a positive impact on workers' motivation if they are committed to a shared corporate culture that incentives them to comply with the social contract and more generally to bind themselves to firm's objectives regardless of the presence of a monetary reward. In this model therefore intrinsic motivation is assumed to be endogenous to the company and dependent on the firm's conduct, while the CSR is considered a discriminating factor.

Training is thus involved in the CSR "contract" in different ways. General training is seen as a form of profit redistribution to workers who will earn higher wages further to their skill improvement. Ethical and relational training is understood as a tool for enabling workers to give proper interpretation of organizational events and to increase their intrinsic motivation through the transmission of a sense of commitment. The increased motivation of workers, in its turn, limits opportunistic behaviour, facilitates implicit and explicit employment relationships, and stimulates the endogenous development of knowledge and skills with a positive impact on firm's competitiveness and long-term organization's performance.

Finally, CSR may play a role because of the merit good nature of knowledge. Indeed it has been defined as the corporate provision of public goods independent of legal benchmark (Besley and Ghatak, 2007). Thus, if government fails to provide impure public goods because of crowding-out effects of political biases, opportunism, incomplete information, CSR can replace it as a better channel to produce them (Kitzmuller and Shimshack 2012). Accordingly, CSR may also be suitable for closing the gap between private and social value of training investments.

\subsection{Public subsidies}

The public sector plays an important role in enhancing training investments. Its main tool is given by subsidies aimed at raising the amount of training through a monetary contribution to training costs. Government grants and tax incentives can be viewed as a typical pigouvian solution to positive externalities generated by firm training. In this model subsidies (or tax deductions) are typically assigned to firms, covering a proportion of the firms' training expenditures. Subsidies are thus expected to increase the level of training investments by reducing their marginal cost. In addition, they may also indirectly support innovation in case of a skill-biased technical change which usually needs a workers' requalification.

Public contribution to training investments is actually widespread, being implemented through both public funds established for this purpose by all government levels (regions, national states, European community) and tax deductions specifically targeted to training firms.

European countries have traditionally pursued these objectives through tax deductions. In 2000 Austria introduced a tax credit of $6 \%$ of the actual training expenses.

Luxembourg (with the Law of 12th February 1999) and the Netherlands (with the Law 1st January 1998, then abolished in 2004) opted for tax deductions from revenues, thus allowing firms to deduct some or all training costs and thereby to reduce corporate 
taxes. Italy as well adopted similar rules in 2001 (with the Law n. 383). Other statutes directly subsidise in-firm training programmes aimed at enhancing vocational skills. A recent application of this policy tool is represented by the provision of Article 1 of the Italian Law Decree n. 78/2009 as it has been turned into Law n. 102/2009. Pursuant to this provision firms that have experienced difficult times during the economic crisis and are involved in income support programs for their workers can employ these workers in on-the-job training projects after signing a specific union agreement. The trained worker will receive a bonus equal to the difference between the income support treatment and the wages he would earn during normal times of production activity. The firm bears the cost of the bonus, while the residual wage is paid by the social security. This rule clearly captures the positive externalities of training.

The same effect can be achieved through a "combination of levies and grants named "train or pay" schemes, with levies payable only if the training investment falls below a legal minimum" (Bassanini et al. 2005, 167). French Law of 16th July 1971 is a wellknown example of this solution, having introduced a minimum training expenditure (currently 1,6\% of total payroll for firms having more than 20 employees) through requiring firms to pay a levy equal to the difference between the minimum and actual investment. This scheme can thus be decomposed into a tax on payroll and a subsidy on training such that the net tax is equal to zero when the minimum required amount of training is attained. If both levies and grants rest on the firms the effect is to encourage training investments by firms by reducing the marginal cost of training for firms complying with the legal threshold. The more the threshold actually discriminates between training and poaching firms the more effective will be the policy measure in specifically addressing poaching externalities by reducing turnover (Moen and Rosen 2002). If instead firms transfer both levies and subsidies onto workers, the effects will be restricted to a redistribution of the worker's income across periods. In this hypothesis the result will alleviate under-investments coming from capital market imperfection thus providing workers with incentives to bear part of training costs (Stevens, 2001).

In the United States training subsidies are directly assigned to trainees through vouchers. According to this mechanism, once an individual is admitted to a training program she will receive one or more certificates that could be used at any training organization that participates to the program. In particular, pursuant to the Workforce Investment Act of 1998, the Federal Government funds training programs devoted to adults and dislocated workers through a network of local entities led by employer representatives (Workforce Investment Boards). Grants are assigned through individual training accounts (ITAs), i.e. vouchers secured by Federal Government that individuals may use to purchase training of their choice, subject to conditions. First, the training program should be related to a "demand occupation", i.e. an occupation for which labour market information suggests a current and continuing need for workers. Second, training providers must be certified as eligible based on their past performance before they can receive referrals for training. Voucher programs are also used in European countries by both national and local governments/agencies (Germany, Italy, Switzerland, Austria, Belgium), although they are not as common as other policy tools. The rationale for training vouchers is similar to the case of vouchers in education as they maximise 
choice and make training organizations compete for participants, thus promoting efficiency. However they are inappropriate for on-the-job training programs which are necessarily provided by the employer.

However, typical risks of "government failure" are associated with subsidies. Governments may suffer from asymmetric information when subsidizing a firm or a worker. The heterogeneity of marginal cost functions faced by training firms can produce deadweight losses in the relevant labour markets. The recipients of the subsidy may engage in opportunistic behaviour through either confusing working hours with training hours or adopting cream-skimming conducts in presence of workers heterogeneity. In addition the time lag between the manifestation of training needs and the implementation of the subsidized training program may negatively affect the effectiveness of government intervention.

Finally, subsidies may just imply a substitution from private to public spending. Such a substitution may still be justified by two reasons: (i) the potential myopic behaviour of the worker, who would tend to favour a higher salary in the initial phase of his working period even in presence of an expected net positive return; (ii) the existence of a budget constraint that, assuming imperfectly competitive capital markets, may not allow the employee to accept a low wage at the beginning of a career, even though he would be willing to do it. However this substitution may also end up with a crowding-out effect that may lower both workers' motivation and firms' incentives to make training as much effective as possible.

The scarce empirical evidence on this issue shows that such policies can anyhow, though not always, determine a positive impact on training investments. Holzer et al. (1993) find that a grant program for manufacturing firms in Michigan increased the amount of training provided by the recipients of the subsidy. Gorg and Strobl (2006) measure a positive effect of government subsidies on training expenditures of Irish firms for domestic plants (while they find no effect for foreign plants). Leuven and Oosterbeek (2004) find no significant effect of a Dutch tax deduction for workers over the age of 40. More recently, Hollenbeck (2009) analyses the effects of the Workforce Investment Act of 1998 finding a positive effect on employment levels and wage rates. Messer and Wolter (2009) measure a positive impact of adult education vouchers on training participation of individuals. Using difference-in-difference estimator, Gorlitz (2010) finds a positive effect of voucher programs on the fraction of firms investing in training programs, while the same programs have no effect on the share of training participants related to the size of the workforce.

\subsection{Labour market regulations and institutions}

A supporting role to training investments can also be played by labour regulation and in particular by employment protection regulation. This category of regulatory tools typically include that bundle of laws governing employment contracts, including minimum wage setting, hiring and firing regulations, working hours flexibility. All these institutions typically restrict the ability of the employer to utilize labour and are usually put into place to reach some other goals than solely fostering training investments. 
Indeed their main goal is employment protection, which is pursued through dismissals restrictions, limitations on the use of fixed-term and temporary contracts, regulation of working hours. These provisions, however, indirectly affect training investments, the extent of this effect depending on their specific content and actual enforcement.

The most common regulatory tool providing incentives for training investments is represented by those provisions that protect workers from being dismissed, e.g. through the introduction of a mandatory just cause that retrenches the employer's freedom to reduce firm's workforce, (Levine 1991; Eger 2004).

Legal rules restricting termination of individual employment contract are in force in all main European countries, although at different levels (European Commission 2006). In Germany, pursuant to the Protection Against Dismissal Act dismissals have to be socially justified. In France the Labour Code requires that dismissal have to rest on well-founded reasons. The Code protects in particular those employees with a limited capability to reenter in the labour market. In UK the Employment Rights Act only allows dismissal for cause, so that termination of the contract must not be seen as unfair in order to be valid. In Italy the Workers' Rights Statute imposes the just cause for employees to be dismissed (this provision however is currently under reform). In Spain the Employees' Statute provides for three possible reasons for dismissal: disciplinary grounds, objective grounds, economic, technical, organisational or production-related grounds (only for collective dismissal).

Conversely in the United States only few states adopted legislations to protect employees against unfair dismissal, while the general rule is the lawfulness of the dismissal "at will", meaning that employers may terminate contracts with or without cause. In some cases such regulatory tools limit the application of dismissal barriers only to certain instances that are more exposed to the risk of firms' opportunistic behaviour (Schwab 1993): (i) newly hired workers (such as regulation of apprenticeship contracts); (ii) workers who have heavily invested in training during their working period without moving to other firms; (iii) workers at the end of their career.

These rules lower the probability of separation after the worker has been trained. High firing costs make firms provide more training to workers than in a deregulated environment because firms are reluctant to fire workers. Moreover training mitigates the costs borne by the firm: "by training a worker, a firm can reduce the risk of having to fire her since the value of a well-trained worker is less likely to turn negative" (Lechtaler $2009,332)$. Legal protection against dismissal may thus address the employer's ex post opportunistic behaviour and create an ex-ante incentive for the worker to participate to specific training activities.

Nonetheless negative effects are also in place. They cause distortions on the incentivestructure of the employment relation. Under information asymmetries low-productivity (and low skilled) workers may benefit from dismissal restrictions as long as they are insiders, thus entailing an adverse selection process. For the same reason they make the separation decision become inefficient. In addition uniform restrictions to individual dismissals not dependent on worker's productivity cause a corresponding increase of 
firing costs. However, if the regulation limits the freedom of the employer with respect to the decision of whom to dismiss, the distribution between low-productivity workers and high productivity ones tends to equalize. In this hypothesis the magnitude of adverse selection would be limited by dismissal protection rules (Bauman 2010). However, even in presence of these drawbacks the regulatory choice may still be justified because of the asymmetric market power that affects the employment relationship. Indeed, due to their bargaining power employers may be reluctant to accept a voluntary contractual protection against dismissal rules.

Empirical evidence in this respect is offered by Bishop (1991) who finds a higher probability of formal training and a greater amount of training investments in presence of a regulatory framework that hinders workers' dismissal. Yet these effects have been recently questioned in the light of the widespread use of temporary contracts that many European countries experienced during the last two decades. The high level of protection attached to the substantially unchanged employment legislation for openended contracts is difficulty compatible with the higher flexibility introduced by the new models of labour contracts for newly hired workers (Dolado e Stucchi 2008). The higher is the level of employment protection and firing costs, the lower will be the firm's propensity to promote temporary workers and eventually to train them.

Similar effects can alternatively be achieved through customary institutions and social norms, such as the German "social plan" and the Japanese "life time employment". The former inhibits firms to proceed on massive layoffs unless they reach an agreement with employee representatives about their extent (Abrahaman e Houseman 1993). The latter guarantees that workers will remain employed in the same firm throughout their working life once recruited (Aoki 1990; Kondo 1990). Not surprisingly, one of the main arguments supporting these institutions is their potential capability to stimulate training investments and human capital development.

Trade unions are another typical institutional device, although it is not obvious whether their role is associated with positive or negative effects on training investments. On the one side unionization of workers may reduce the effect of poaching externalities by promoting wages harmonization at the industry level (Booth and Chatterji 1998) and reducing turnover (Booth et al. 1999). On the other side trade unions may favour a compressed wage structure with ambiguous effects in term of training investments, mainly depending on the degree of competition in the labour market and on whether the union effect on training is indirect (through the wage structure) or direct (through the negotiation of training). Consistently with these theoretical insights the related empirical evidence is twofold. Duncan and Stafford (1980) measure a reduction in training intensity associated with union membership in the US. Booth (1991) shows that union membership resulted in increased training in the UK. Still in the UK Green (1993) finds that union membership increases personnel training in companies with less than 25 employees, but had no impact in larger companies. Boot and Francesconi (2003) find that employees working under union collective agreements are more likely to receive training and obtain a net benefit in the form of wage increases than other employees. 
The imposition of a minimum wage can also promote training investments as firms need to obtain a threshold level of productivity from all workers. Moreover, under a minimum wage constraint, an increase of labour productivity generated by training may not imply a rise in the wage, thus increasing firm's benefit stemming from training investments (Acemoglu and Pischke 2003). On the other side minimum wages may inhibit training costs sharing in the initial stages of the worker's career through preventing wages to fall at the required level (Leuven 2005). In the same sense, minimum wages may generate a "firing effect" on low-skilled workers for whom the difference between wages and productivity would become negative (Lechtaler and Snower 2006). The result is an increased probability of these workers to be dismissed which, in its turn, lowers the incentive to train them. This negative effect is even exacerbated by the risk that the provision of a minimum wage would incentive unskilled workers to enter the labour market without enjoying a previous education and/or training period (Ippolito 2003). An unskilled workforce in its turn would inhibit firms from investing in training due to the complementarities between education and work-related training. Finally, minimum wage may negatively affect extrinsic motivation by inhibiting flexible wage schemes. Empirical studies confirm these ambiguous effects as conflicting findings are reported in the literature dealing with the impact of the minimum wage on training (Schiller 1994; Neumark and Wascher 2001; Acemoglu and Pischke 2003; Arulampalam et al. 2004).

$<$ Table 2 about here $>$

The regulatory content however is not sufficient to determine its actual effects on training investments. The magnitude of regulatory costs, the enforceability of employment protection rules, firms' characteristics (both in terms of technology and in terms of human capital) are all variables that shape the actual effect of regulation on training investments. Moreover most of the reforms of employment protection regulation serve other purposes than increasing training investments. Not surprisingly, the empirical findings in terms of the impact of labour market regulation on training investments are quite contradictory (Woessmann 2006).

\section{Conclusions}

This paper provides an overview of legal and institutional solutions to underinvestment in training according to a law and economics perspective. Given that labour markets are actually characterized by a less than optimal level of training, the paper conceptualized four families of legal and institutional devices that may address these inefficiencies: contracts, Corporate Social Responsibility (CSR), public subsidies (or their equivalent), labour market regulation. Property rights are excluded from the survey because they are assumed not to be tradable. Then the paper points out the economic effects of these mechanisms, emphasizing the trade-offs associated with each relevant variable.

Table 3 shows a taxonomy of the main legal and institutional tools for addressing inefficiencies in training investments. Positive, neutral and negative effects are referred to plus, minus, and equal sign, respectively. The term "amb" is used for practices involved in a trade-off concern. 
$<$ Table 3 about here $>$

According to the source of inefficiency the possible solution may change. All the contractual remedies are suitable for reducing poaching externalities. However, because of the existence of a third party (the poaching firm) that cannot participate to the transaction, these contractual schemes are not automatically a successful strategy for solving this problem. All the such schemes are not specifically tailored for addressing poaching externalities. As a consequence they are often accompanied by negative side effects. Given that the research for an optimal contractual structure addressing poaching in training investments has not yet been subject of the whole academic study it deserves, this is a promising area for further studies.

Contractual remedies are usually the first tool to be taken into account for addressing information asymmetries as well. The training firm may better observe worker's ability and effort than either the market or the government. In this case firms and workers may agree on a scheme that bargains initially lower wages with the employee's right to receive a training package and the opportunity to get a subsequent wage increase if the worker is retained. However, these contracts embody a risk of opportunistic behaviour. If this is the case such contractual schemes should be accompanied either by a regulation that defines the length of apprenticeships contract or by a subsidy for completed spells of training.

Workers' low propensity to accept training schemes and contractual incentives could be faced through the adoption of a voluntary CSR policy. CSR is supposed to attract intrinsically motivated job applicants and to increase workers' propensity to share training costs thanks to the reputation it entails. In this respect CSR may serve as a vehicle for integrating or substituting extrinsic incentives attached to a partially flexible wage with intrinsic motivation. Moreover, in an institutional perspective, according to which CSR is a social norm that commits firms to tie together the preferences of shareholders with the ones of stakeholders, training investments could become one of the possible issues of agreement between firm and workers in order to derive an equilibrium among their different objectives.

Knowledge spillovers and positive externalities would justify subsidies (or tax deductions) assigned to training firms. These subsidies may address them by letting the government pay a share of the firms' training expenditures, thus lowering training costs borne by the firm (supply-side). Subsidies to trainees (demand-side), in the form of vouchers, may instead tackle capital market imperfections. However the fundamental difference between employer-provided training and training provided by external organizations should be taken into account when choosing the recipient of the subsidy. Concerning the drawbacks of subsidies, it must be noticed that training vouchers may reduce extrinsic motivation due to the absence of any incentive scheme attached to worker's effort. At the same time subsidies are expected to have negative effects on intrinsic motivation due to crowding-out effects.

Regulation is usually appropriate for reducing poaching externalities without increasing transaction costs. The drawbacks are mainly related with information asymmetries that 
plagues the policy maker. Like subsidies, regulation may fail because the policy maker faces a monitoring problem to ensure that the resultant training is an appropriate quantity. Moreover, employment protection regulation reduces extrinsic motivation due to the low monetary incentive it entails.

It must be also stressed that the presence of generic market failures in the labour market is not enough to justify a policy intervention, since in imperfect labour markets firms may have higher incentives to sponsor general training. On the other side a competitive labour market usually calls for subsidies and/or regulation.

The final remark is that theory alone does not tell us enough. Firstly, it is difficult to assess rigorously all the different legal and institutional solutions able to address training investments. Secondly, the heterogeneity of the potential sources of inefficiencies makes it difficult to arrive to clear-cut policy recommendations. Additionally, the lack of evidence on the actual causes of the under-provision of training suggests being cautious before advocating a single resolving policy intervention. What is clear then is that a preliminary investigation of the main causes of the under-provision of training in the relevant labour markets - on the basis of country-specific empirical assessment - should be performed before assisting the policy maker in choosing the efficient mix of legal and institutional tools. Very often, indeed, a combination of different policy tools is desirable due to the multiple trade-offs associated with the involved variables. Hopefully this contribution may serve as a preliminary tool-box for the policy maker willing to promote training investments through such a combination.

\section{References}

Abraham, K.G., Houseman, S.N. (1993). Job Security in America: Lessons from Germany. Washington D.C.: The Brookings Institution.

Acemoglu, D. (1997). Training and Innovation in an imperfect labour market. Review of Economic Studies, 64, 445-464.

Acemoglu, D. (2002). Technical Change, Inequality, and the Labor Market. Journal of Economic Literature, 40, 7-72.

Acemoglu, D., Pischke, J. S. (1998). Why do firms train? Theory and evidence. The Quarterly Journal of Economics, 113, 79-119.

Acemoglu, D., Pischke, J. S. (1999). Beyond Baker: Training in imperfect labour markets. Economic Journal, 109, F112-F142.

Acemoglu, D., Pischke, J.S. (2003). Minimum wages and on-the-job training. Research in Labor Economics, 22, 159-202.

Almeida, R., Carneiro, P. (2009). The return to firm investments in human capital. Labour Economics, 16, 97-106.

Antonelli, G., Antonietti, R., Guidetti, G. (2010). Organizational change, skill formation, human capital measurement: evidence from Italian manufacturing firms. Journal of Economic Surveys, 24, 206-247. 
Aoki, M. (1990). Toward an Economic Model of the Japanese Firm. Journal of Economic Literature, 28, 1-27.

Arulampalam, W., Booth, A. L., Bryan, M. L. (2004). Training and the minimum wage. The Economic Journal, 114, C87-C94

Autor, D. H. (2001). Why do temporary help firms provide free general skills training? Quarterly Journal of Economics, 116, 1409-48.

Ballot, G., Fakhfakh, F., Taymaz, E. (2001). Firms' human capital, R\&D and performance: a study on French and Swedish firms. Labour Economics, 8, 443-462.

Barrett., A. O'Connell, P. J. (2001). Does training generally work? The return of in-company training. Industrial and Labour Relation Review, 54, 623-655.

Barron, J. M., Black, D., A., Loewenstein, M. A. (1989). Job matching and on-the-job training. Journal of Labor Economics, 7(1), 1-19.

Bartel, A. P. (1994). Productivity gains from the implementation of employment training programs. Industrial Relations, 33, 411-425.

Bartel, A.P. (1995). Training, wage growth, and job performance: evidence from a company database. Journal of Labor Economics, 13, 401-425.

Bassanini, A., Booth, A., Brunello, G., De Paola, M., Leuven, E. (2005). Workplace training in Europe, IZA Discussion Paper N. 1640.

Bauman, F. (2010). On unobserved worker heterogeneity and employment protection. European Journal of Law and Economics, 29, 155-175.

Becker, G. S. (1964). Human Capital. New York: National Bureau of Economic Research.

Besley, T., Ghatak, M. (2007). Retailing public goods: the economics of Corporate Social Responsibility. Journal of Public Economics, 91, 1645-63.

Bishop, J. (1991). On-the-job training of new hires, in: D. Stem, J. Ritzen, (Eds.), Market Failure in Training. New York: Springer Verlag.

Bishop, J. (1994). The impact of previous training on productivity and wages. In Lynch, L. (Ed.) Private sector and skill formation: international comparisons (161-199). Chicago: Univ. of Chicago Press.

Black, S., Lynch, L. (2001). How to compete: the impact of workplace practices and information technology on productivity. The Review of Economics and Statistics, 83, 434-445.

Blanchflower, D., Lynch, L. (1994). Training at work: a comparison of U.S. and British youths. In Lynch, L. (Ed.) Private sector and skill formation: international comparisons (233-260). Chicago: Univ. of Chicago Press.

Booth, A. (1991). Job-related formal training: who receives it and what is it worth? Oxford Bulletin of Economics and Statistics, 53, 281-294.

Booth, A., Bryan, M. (2002). Who pays for general training? New evidence for British men and women. IZA Discussion Paper No. 486. 
Booth, A., Chatterji, M. (1998). Unions and efficient training. The Economic Journal, 108, 328-343.

Booth, A., Francesconi, M., Zoega, G. (1999). Training, rent-sharing and unions. CEPR Discussion Paper Series N. 2200.

Booth, A., Francesconi, M. (2003). Union coverage and non-standard work in Britain. Oxford Economic Papers, 55(3), 383-416.

Brekke, K. A., Nyborg, K. (2005). Moral hazard and moral motivation: Corporate social responsibility as labour market screening. Oslo University Department of Economics Memorandum 25/2004.

Bresnahan T. F., Brynjolfsson E., Hitt M.L. (2002), Information technology, workplace organization, and the demand for skilled labor: firm-level evidence. The Quarterly Journal of Economics, 117, 339-374.

Brown, J. N. (1989). Why do wages increase with job tenure? On-the-job training and life-cycle wage growth observed within firms. American Economic Review, 79(5), 971-991.

Brunello, G., De Paola, M. (2004). Market failures and the under-provision of training. Cesifo Working Paper n. 1286.

Carriou, Y., Jeger, F. (1997). La formation continue dans les enterprises et son retour sur investissement. Economie et Statistique, 303, 45-58.

Casas-Arce, P. (2004). Firm provision of general training and specific human capital acquisition. University of Oxford Department of Economics Discussion Paper Series N. 198

Chang, C., Whang, Y. (1996). Human capital investment under asymmetric information. The pigouvian conjecture revisited. Journal of Labor Economics, 14, 505-519

Collier, J., Esteban, R., and Street, T. (2007). Corporate social responsibility and employee commitment. Business Ethics: A European Review, 16(1), 19-33

Conti, G. (2005). Training, productivity and wages in Italy. Labour Economics, 12, 557-576.

Dearden, L., Reed, H., Van Reenen, J. (2006). The impact of training on productivity and wages: evidence from British panel data. Oxford Bullettin of Economics and Statistics, 68(4), 397-421.

Den Hertog, J. (2003). Non-competition clauses: unreasonable or efficient? European Journal of Law and Economics, 15, 111-127.

Dolado, J. J., Stucchi, R. M. (2008). Temporary workers and firms' productivity: Evidence from the Spanish manufacturing sector. CEPR Discussion Paper No. 7055.

Duncan G.,J., Stafford, F.P. (1980). Do union members receive compensating differentials? American Economic Review, 70, 355-381.

Edlin, A. S., Hermalin, B. E. (2000). Contract renegotiation and options in agency problems, Journal of Law, Economics and Organization, 16, 395-423.

Eger, T. (2004). Opportunistic termination of employment contract and legal protection against dismissal in German and the USA, International Review of Law and Economics, 23, 381-403. 
European Commission (2002). Communication on Corporate Social Responsibility: a business contribution to sustainable development. Bruxelles.

European Commission (2006). Termination of employment relationship. Legal situation in the Member States of the European Union. Luxembourg.

Fees, E., Mulheuber, G. (2002). Economic consequences of transfer fee regulations in European football. European Journal of Law and Economics, 13, 221-237.

Fella, G. (2005). Termination restrictions and investment in general training. European Economic Review, 49(6), 1479-1499.

Finegold, D., Soskice, D. (1988). The failure of training in Britain: analysis and prescription. Oxford Review of Economic Policy, 4, 2I-53.

Franz, W., Soskice, D. (1995). The German apprenticeship system. In Buttler, F., Franz, W., Schettkat, R. (Eds.) Institutional frameworks and labor market performance: comparative views on the US and German economies (208-234). London: Routledge.

Frazis, H., Loewenstein, M. A. (2005). Reexamining the returns to training: functional form, magnitude, and Interpretation. The Journal of Human Resources, 40(2), 453-476.

Frey, B. (1997). Not just time money: an economic theory of personal motivation. Chelthenam: Edward Elgar.

Frey, B., Jegen R. (2001). Motivation Crowding Theory. Journal of Economic Surveys, 15, 589-611.

Friedman, M. (1995). The social responsibility of business is to make profits, reprinted in: W. M., Hoffman, R. E. Frederick (Eds.), Business Ethics. New York: Mc-Graw Hill.

Garmaise, M. (2009). Ties that truly bind: noncompetition agreements, executive compensation and firm investment. Journal of Law, Economics and Organization, 3, 1-50.

Green, F. (1993). The impact of trade union membership on training in Britain. Applied Economics, 25(8), 1033-1043.

Griliches, Z., Mairesse, J. (1998). Production functions: the search for identification. In Strøm S. (ed.) Econometrics and economic theory in the 20th century (169-203). Cambridge: Cambridge University Press.

Görg, H., Strobl, E. (2006). Do government subsidies stimulate training expenditure? Microeconometric evidence from plant-level data. Southern Economic Journal, 72 (4), 860-876.

Gorlitz, K. (2010). The effects of subsidizing continuous training investment. Evidence from Germany establishment data. Labour Economics, 17, 789-798.

Groot, W. (1999). Productivity effects of enterprise-related training. Applied Economic Letters, 6(6), 369-71.

Guidetti, G., Mazzanti, M. (2007). Firm training activities and complementarities in production: conceptual insights and empirical evidence. Journal of Socio-Economics, 36(6), 875-94.

Hansson, B. (2007). Company-based determinants of training and the impact of training on company performance: results from an international HRM survey. Personnel Review, 36 (2), 311331 
Hermalin, B. (2002). Adverse selection, short-term contracting, and the underprovision of on-thejob training. Contributions to Economic Analysis \& Policy, 1(1), 1-19.

Hollenbeck, K. (2009). Does the Workforce Investment Act work?. Paper presented at the 31st Annual Research Conference of the Association for Public Policy Analysis and Management (APPAM), Washington DC 6 November.

Hollenbeck, K., Wilkie, R. (1985). The nature and impact of training: evidence from the current population survey. In J. Bishop (Ed.) Training and human capital. Columbus: Ohio State University, National Center for Research in Vocational Education.

Holzer, H. J., Block R. N., Cheatham M., Knott, J. H. (1993). Are training subsidies for firms effective? The Michigan experience. Industrial and Labor Relations Review, 46 (4), 625-636.

Ippolito, R.A. (2003). The Impact of minimum wage if workers can adjust effort. Journal of Law and Economics, 46, 207-227.

Kahn, C., Huberman, G. (1988). Two sided uncertainty and "up-or-out" contracts. Journal of Labour Economics, 6, 423-44.

Katz, E., Ziderman, A. (1990). Investment in General Training: The Role of Information and Labour Mobility. The Economic Journal, 100, 1147-1158.

Kessler, A.S., Lulfesmann, C. (2006). The theory of human capital revised: on the interaction of general and specific investments. The economic journal, 116, 903-923.

Kitzmuller, M., Shimshack, J. (2012). Economic perspectives on Corporate Social Responsibility. Journal of Economic Literature, 50, 51-84.

Kondo, D.K. (1990). Crafting selves: power, gender, and discourses of identity in a Japanese workplace. Chicago: University of Chicago Press.

Konings, J., Vanormelingen, S. (2010). The impact of training on productivity and wages: firm level evidence. IZA Discussion Papers, No. 4731

Krueger, A., Rouse, C. (1998). The effects of workplace education on earnings, turnover, and job performance. Journal of Labor Economics, 16(1), 61-94.

Kugler, A. D., Saint-Paul, G. (2004). How do firing costs affect worker flows in a world with adverse selection? Journal of Labour Economics, 22, 553-584.

Lechthaler, W. (2009). The interaction of firing costs and firm training. Empirica, 36, 331-350.

Lechthaler, W., Snower, D. J. (2006). Minimum Wages and Firm Training. The Kiel Institute for the World Economy Working Paper No. 1298.

Leuven, E. (2005). The Economics of private sector training: a survey of the literature. Journal of Economic Surveys, 19, 91-111.

Leuven, E., Oosterbeek, H. (2004). Evaluating the effect of tax deductions on training. Journal of Labor Economics, 22(2), 461-488.

Levine, D. J. (1991). Just-cause employment policies in the presence of worker adverse selection. Journal of Labour Economics, 9, 294-305. 
Lillard, L., Tan, H. (1986). Private Sector Training: Who Gets it and What are Its Effects. Santa Monica: Calif. Rand Corp.

Loewenstein, M. A., Spletzer, J. R. (1999). General and specific training: evidence and implications. The Journal of Human Resources, 34, 710-733.

Lynch, L. (1992). Private sector training and the earnings of young workers. American Economic Review, 82, 299-312.

Malcomson, J., Maw, J. , McCormick, B. (2003). General training by firms, apprentice contracts, and public policy, European Economic Review, 47, 197-227.

Manning, A. (2003). Monopsony in Motion: Imperfect Competition in Labor Markets. Princeton: Princeton University Press.

Marshall, A. (1920). Principles of Economics. An Introductory Volume. London: Macmillan and Co..

Maximiano, S., Oosterbeek, H. (2007). On the determinants of workers' and firms' willingness to train. Paper presented at the XXV Conference of the European Association of Law and Economics, Oslo 20-22 September.

Messer, D., Wolter, S.C. (2009). Money matters: evidence from a large-scale randomized field experiment with vouchers for adult training. IZA Discussion Paper No. 4017

Mincer, J. (1958). Investment in human capital and personal income distribution. Journal of Political Economy, 66, 281-302.

Mincer, J. (1988). Job-training, wage growth and labor turnover. NBER Working Paper N. 2690.

Moen E. R., Rosén A. (2004). Does Poaching Distort Training? The Review of Economic Studies, 71, 4 pp. 1143-1162.

Moretti, E. (2010). Local labor markets. IZA Discussion Papers No. 4905.

Mohrenweiser, J. , Backes-Gellner, U. , Zwich, T. (2010). Poaching and firm sponsored training: first clean evidence. GEABA Discussion Papers 10-16.

Muehlemann S., Wolter C. S. (2011). Firm-sponsored training and poaching externalities in regional labor markets. Regional Science and Urban Economics, 41, 560-570

Neumark, D., Wascher, W. (2001). Minimum wages and training revisited, Journal of Labor Economics, 19, 563-95.

Nickell, S. (1998). Unemployment: questions and some answers, Economic Journal, 108, 802-816.

Prendergast, C. (1993). The role of promotion in inducing specific human capital acquisition.

Quarterly Journal of Economics, 108, 523-34.

Picchio, M., Van Ours, J. C. (2011). Market imperfections and firm-sponsored training, Labour Economics, 18(5), 712-722.

Rajan, R. G., Zingales L. (1998). Power in a theory of the firm. The Quarterly Journal of Economics $113,387-432$.

Rosen, S. (1976). A theory of life earnings. Journal of Political Economy, 84, S45-S67. 
Rubin, P. H., Shedd P. (1981). Human Capital and Covenants Not to Compete. Journal of Legal Studies, 10, 93-110.

Sacconi, L. (1997). Economia, etica, organizzazione: il contratto sociale dell'Impresa. Roma: Laterza.

Sacconi, L. (2005). Guida critica alla responsabilità sociale d'impresa, problemi, teorie e applicazioni della CSR. Roma: Bancaria Editrice.

Sarti, D., Hulkko-Nyman, K. (2011). Politiche retributive e impegno sul lavoro. Evidenze empiriche dalle professioni del welfare. Economia dei servizi, 3, 321-340.

Schiller, B. R. (1994). Moving up: the training and wage gains of minimum wage entrants. Social Science Quarterly, 75, 622-36.

Schlicht, E. (1996). Endogenous on-the-job training with moral hazard. Labour Economics, 3, 8192.

Schwab, S. J. (1993). Life-cycle justice: accomodating just cause and employment at will. Michigan Law Review, 95, 8-58.

Sepulveda, F. (2010). Training and productivity: evidence for US manufacturing industries. Oxford Economic Papers, 62, 504-528.

Stevens, M. (1996). Transferable training and poaching externalities. In A. L. Booth, D. J. Snower (Eds.) Acquiring Skills. Cambridge: Cambride University Press.

Stevens, M. (2001). Should firms be required to pay for vocational training? The Economic Journal, 111, 485-505.

Tan, H., Chapman, B., Peterson C., Booth, A. Youth (1992). Training in the US, Britain and Australia. Research in Labor Economics, 13, 63-99.

Veum, J. (1995). Sources of training and their impact on wages. Industrial and Labour Relations Review, 48(4), 812-826.

Woessmann, L. (2009). Efficiency and equity of European education and training policies. CESifo Working paper No. 1779.

Wolf, E. N. (2000). Human capital investment and economic growth: exploring the cross-country evidence. Structural Change and Economic Dynamics, 11, 433-472.

World Business Council for Sustainable Development (2000). Corporate Social Responsibility: Making Good Business Sense. Geneve.

Zwich, G. (2002). Continuous training and firm productivity in Germany, ZEW Discussion Papers 02-50. 